\title{
A SUDDEN DEATH ASSOCIATED WITH THE USE OF SODIUM NITROPRUSSIDE FOR INDUCTION OF HYPOTENSION DURING ANAESTHESIA
}

\author{
David W. Davies, Dezso Kadar, David J. Steward, and Ian R. Munro
}

\section{INTRODUCTION}

SoDIUM NITROPRUSSIEE was first used clinically in $1929 .{ }^{1}$ Since 1962 , it has been used increasingly by infusion of a 0.01 per cent solution to achieve controlled hypotension during surgery. ${ }^{2-4}$ Previous publications have attested to its potency, efficacy and, with due precautions, its safety due to the evanescent action. They do not point out the inherent toxic properties of this drug. Since no dosage range had been suggested for sodium nitroprusside as a hypotensive agent during anaesthesia, the dosage has been selected on an empirical basis to provide the degree of hypotension required. Hypertensive patients are particularly sensitive to the action of sodium nitroprusside, but young, healthy males may be relatively resistant or may develop tachyphylaxis. ${ }^{6}$

In the fatal case described, sodium nitroprusside was used during general anaesthesia in a 14-year-old boy undergoing bilateral saggital mandibular osteotomies for retrognathia. After extensive postmortem investigation, it was ascertained that the boy died of cyanide poisoning, complicated by a possible inherited defect of cyanide metabolism. This incident occurred in June 1974.

\section{Case Report}

The patient was a healthy $40 \mathrm{~kg}$ white male with no significant personal or family history. He had previously had five uneventful general anaesthetics for middle-ear problems. Preoperative haemoglobin was $14.2 \mathrm{gm}$ per $100 \mathrm{ml}$ and the urine was negative for sugar and albumin. Following overnight fasting he received meperidine $40 \mathrm{mg}$ intramuscularly two hours preoperatively.

Anaesthesia was induced with 2.5 per cent sodium thiopentone, $250 \mathrm{mg}$, and atropine $0.6 \mathrm{mg}$ intravenously. Succinylcholine $40 \mathrm{mg}$ intravenously, facilitated nasal tracheal intubation.

Anaesthesia was maintained for the next 20 minutes with nitrous oxide 7 litres/ min, oxygen 3 litres/min and halothane, the patient breathing spontaneously. During this time two intravenous infusion routes were established, one for fluid therapy during operation and the other solely for the planned infusion of sodium nitroprusside. The left radial artery was cannulated to monitor blood pressure continuously.

Departments of Anaesthesia, Pharmacology and Plastic Surgery, Hospital for Sick Children, - Toronto, and University of Toronto. 
TABLE I

Arterial Bloon Gases at $37^{\circ} \mathrm{C}$

\begin{tabular}{|c|c|c|c|c|c|c|c|}
\hline & \multirow{2}{*}{$\begin{array}{l}15 \mathrm{~min} \\
\text { prior } \\
\text { to SNP }\end{array}$} & \multicolumn{2}{|c|}{$\begin{array}{l}\text { Time after SNP } \\
\text { administration }\end{array}$} & \multirow{2}{*}{$\begin{array}{l}\text { At time of } \\
\text { arrest }\end{array}$} & \multicolumn{2}{|c|}{ Time after arrest } & \multirow[b]{2}{*}{ Terminal } \\
\hline & & $50 \mathrm{~min}$ & $80 \mathrm{~min}$ & & $15 \mathrm{~min}$ & 1 hour & \\
\hline $\mathrm{pH}$ & 7.48 & 7.48 & 7.27 & 6.92 & 7.04 & 7.16 & 7.42 \\
\hline $\mathrm{PCO}_{2}$ & & & 19 & 17 & 58 & 64 & 22 \\
\hline $\mathrm{Po}_{2}$ & 164 & 137 & 132 & 382 & 68 & 93 & 340 \\
\hline $\mathrm{BE}$ & -9 & -5 & -12 & -21 & -17 & -8 & -8 \\
\hline $\mathrm{HCO}_{3}$ & $\mathrm{NM}$ & 19 & $\mathrm{NM}$ & NM & 15 & 22 & 13 \\
\hline $\mathrm{FIo}_{2}$ & 0.3 & 0.3 & 0.3 & 1.0 & 1.0 & 1.0 & 1.0 \\
\hline
\end{tabular}

$\mathrm{SNP}=$ sodium nitroprusside.

$\mathrm{NMI}=$ not measured.

This established, halothane was discontinued and anaesthesia was maintained with d-tubocurarine, fentanyl and droperidol with controlled ventilation. The systolic arterial pressure at this time was $110 \mathrm{~mm} \mathrm{Hg}$.

With the patient in 10 degrees head-up position, mandibular and maxillary arch bars were wired in place. An infusion of sodium nitroprusside was commenced using a Plexitron microdrip infusion set (Baxter Laboratories of Canada, Ltd., Malton, Ontario). Within five minutes of starting sodium nitroprusside, the systolic arterial pressure was $60 \mathrm{~mm} \mathrm{Hg}$, necessitating a free-running infusion. After 10 minutes, the systolic blood pressure had risen to $75 \mathrm{~mm} \mathrm{Hg}$ and would not go lower. Despite increased dosage of sodium nitroprusside and reintroduction of halothane ( 0.5 per cent increasing to 1.0 per cent) for a 15 -minute period the systolic arterial pressure fluctuated between 65 and $75 \mathrm{~mm} \mathrm{Hg}$. Since the halothane did not help to lower the blood pressure it was discontinued. After 80 minutes, when the definitive osteotomies were completed and the mandible was being wired, the sodium nitroprusside was discontinued. During the 80 minutes of infusion the patient received approximately $120 \mu \mathrm{g} / \mathrm{Kg} / \mathrm{min}$ ( $10 \mathrm{mg}$ per $\mathrm{Kg}$ ) of sodium nitroprusside for a total dose of approximately $400 \mathrm{mg}$.

Two minutes after sodium nitroprusside was discontinued the systolic arterial pressure rose from 70 to $75 \mathrm{~mm} \mathrm{Hg}$, but during the next 30 minutes it dropped to $50 \mathrm{~mm} \mathrm{Hg}$. During this period the patient was pink, well perfused and had a cardiac apex rate of 120 per minute. He then developed a bradycardia of 40 beats per minute. Atropine $0.4 \mathrm{mg}$ was given intravenously, the operating table made horizontal, and ventilation with 100 per cent oxygen was started. Following this the heart rate increased to 80 beats per minute and the systolic arterial pressure to $70 \mathrm{~mm} \mathrm{Hg}$.

Arterial blood gases during the procedure are shown in Table I and 7.5 per cent sodium bicarbonate was used at intervals to a total of $400 \mathrm{mEq}$ to treat the metabolic acidosis.

Five minutes after atropine administration, the systolic arterial pressure and apex rate fell further. Atropine $0.6 \mathrm{mg}$ and phenylephrine to a total of $16 \mathrm{mg}$ were given intravenously with no effect. Circulatory arrest occurred shortly thereafter. All measures of cardiopulmonary resuscitation were applied without avail.

Autopsy was carried out about 20 hours after death, and besides generalized 
passive congestion of brain and other organs, there was a nonmalignant cyst on the thymus gland. The cyanide content of autopsy blood was $0.5 \mathrm{mg} \%$ as measured by the method of Aldridge ${ }^{7}$ with Boxer and Rickard's modification, ${ }^{8}$ and it was 0.3 $\mathrm{mg} \%$ in the urine. The concentration of sodium nitroprusside was not measured and thiocyanate could not be detected in either blood or urine as measured by these methods.

\section{Discussion}

This case should be a reminder to all those who use or plan to use sodium nitroprusside, especially for induction of hypotension during anaesthesia that it is potentially very toxic. In blood, sodium nitroprusside releases cyanogen, then cyanide. Tissue rhodenase, an enzyme richly available in liver, brain, kidneys and mucous membranes, normally converts the cyanide to the less toxic thiocyanate. This metabolic pathway requires endogenous thiosulphate for its maintenance. Under normal circumstances the rate limiting factor is the availability of thiosulphate rather than the enzyme concentration. ${ }^{9}$ However, the rate of this reaction in vivo is probably far slower than we originally thought and as Vesey et al. ${ }^{4}$ has recently shown, very small increases of thiocyanate but large increases in cyanide occur in blood during the use of sodium nitroprusside in anaesthesia.

Thiocyanate toxicity in the form of decreased thyroid function has been reported with long-term use of thiocyanate ${ }^{10}$ and sodium nitroprusside. ${ }^{11}$ There have been no reports of cyanide toxicity during infusion of sodium nitroprusside. In theory such an occurrence is unlikely because of the ease with which tissue rhodenase handles relatively large amounts of cyanide, providing there are adequate amounts of endogenous thiosulphate available. The first death reported since the introduction of the drug as a hypotensive agent occurred 32 hours after sodium nitroprusside administration was discontinued. ${ }^{12}$ The lethal dose of sodium nitroprusside for an adult is reported to be $1 \mathrm{~g}$, and discontinued administration is the recommended treatment in overdose. ${ }^{13}$ The lethal dose of potassium cyanide is about $200 \mathrm{mg}$. Since sodium nitroprusside will produce almost 50 per cent cyanide, $1 \mathrm{~g}$ would release more than twice the lethal dose of cyanide. This discrepancy is explained probably by the observation that cyanide is released slowly from nitroprusside in blood in vitro ${ }^{5}$ and may also release nitrite, which increases the methaemoglobin concentration: The affinity of cyanide for methaemoglobin is greater than for the cytochrome oxidases.

The patient's blood and urine showed high cyanide levels and virtually no thiocyanate. The absence of thiocyanate in either blood or urine indicates that the patient was unable to detoxify cyanide. The enzyme erythrocytic thiocyanate oxidase theoretically could have converted the thiocyanate to cyanide post mor$\operatorname{tem}^{14}$ and this may explain the absence of thiocyanate from the blood but not from the urine. The urine was not contaminated with blood. It would seem, therefore, that the dynamic thiocyanate-cyanide equilibrium was grossly upset. One of three mechanisms seems to be at fault. There may have been an inadequate supply of endogenous thiosulphate, or a deficiency or inadequacy of tissue rhodenase to clear the amounts of cyanide formed, or inhibition of the rhodenase enzyme by the other drugs, or a combination of these three. 
The only known pathological states in which abnormal cyanide metabolism and consequently increased cyanide levels are an aetiological factor are hereditary Leber's optic atrophy and tobacco ambylopia. ${ }^{14}$ In these conditions an increased cyanide level is a concomitant finding.

In our patient, metabolic acidosis was associated with the use of sodium nitroprusside probably as the result of cyanide poisoning of cellular cytochrome oxidase and consequent tissue anaerobic glycolysis. The post-mortem concentration of the rhodenase enzyme in the liver was not measured.

Our previous experience with sodium nitroprusside in infants and children during "balanced anaesthesia" indicates that they need higher doses of the drug than has usually been indicated for adults during halothane anaesthesia. We fully recognize that our patient received a high dose of sodium nitroprusside (120 $\mu \mathrm{g} / \mathrm{Kg} / \mathrm{min}$ ). However, according to the literature, $400 \mathrm{mg}$ over 80 minutes while continuously monitoring intra-arterial pressure to safe levels is regarded as quite safe and is well within the stated lethal dose of $1 \mathrm{~g}$. The question of why some people fail to respond fully to large doses of sodium nitroprusside remains.

The lethal dose of cyanide is about $3 \mathrm{mg}$ per $\mathrm{Kg}$ which is equivalent to approximately $7 \mathrm{mg}$ per $\mathrm{Kg}$ of sodium nitroprusside. We therefore recommend unequivocally that the use of sodium nitroprusside as a hypotensive agent should not be on an empirical basis only related to the blood pressure desired but also with a projected total dose assessed from the initial response which achieves the blood pressure required. If this projected dose exceeds $3.5 \mathrm{mg}$ per $\mathrm{Kg}$ (half the probable lethal dose) for the anticipated duration of hypotension it might indicate that the patient is probably "cyanide intolerant."

Cyanide-intolerant patients show a relative resistance to the action of sodium nitroprusside in that low levels of hypotension (systolic arterial pressure $50 \mathrm{~mm}$ $\mathrm{Hg}$ ) cannot be achieved or maintained. If a patient appears to be resistant the drug should be immediately discontinued.

The use of the antidotes sodium nitrite, amyl nitrite, sodium thiosulphate and hydroxycobalamin should be considered if a near-toxic dose of sodium nitroprusside has been used. Sodium nitrite $5 \mathrm{mg}$ per $\mathrm{Kg}$ in $20 \mathrm{ml}$ water given intravenously over 3 to 4 minutes, or the inhalation of amyl nitrite for 30 seconds every 2 minutes, will produce methaemoglobin which has a much higher affinity for cyanide than the cytochrome oxidases. Sodium thiosulphate $150 \mathrm{mgm} / \mathrm{Kg}$ in $50 \mathrm{ml}$ water intravenously will supply sufficient substrate for rhodenase to react with cyanide.

The possible effects of hypothermia should also be considered, since maximally vasodilated patients readily become hypothermic. Red blood cell thiocyanate oxidase acts optimally at $\mathrm{pH} 7.4$ and temperature $40^{\circ} \mathrm{C}$, and consequently the hypothermic patient will metabolize thiocyanate to cyanide slower than he normally would. Though this may afford some protection to the "cyanide-intolerant" individual during operation, it could lead to the patient being overwhelmed by cyanide when rewarmed in his bed in the postanaesthetic recovery period.

\section{SUMMARY}

A death from cyanide poisoning during operation was attributable to the use of approximately $400 \mathrm{mg}$ (10 $\mathrm{mg}$ per $\mathrm{Kg}$ ) sodium nitroprusside as an hypotensive 
agent. Autopsy cyanide levels of $0.5 \mathrm{mg}$ per cent in blood and $0.3 \mathrm{mg}$ per cent in urine and thiocyanate levels too low to measure in either, suggest an abnormality of cyanide metabolism. The lethal dose of sodium nitroprusside appears to be $7 \mathrm{mg}$ per $\mathrm{Kg}$. A safe regimen would be $3.5 \mathrm{mg}$ per $\mathrm{Kg}$ as the anticipated total dose for the period of hypotension. Patients resistant to the full hypotensive effects of sodium nitroprusside, or unable to maintain the level of hypotension, or requiring more than $3.5 \mathrm{mg}$ per $\mathrm{Kg}$ to achieve the required effect for the anticipated time, may accumulate toxic levels of cyanide in the blood.

Patients with Leber's optic atrophy, tobacco amblyopia and possibly those with other nerve atrophies should not receive sodium nitroprusside or any other cyanide precursor.

\section{RÉSUMÉ}

Les auteurs rapportent un décès per-opératoire par empoisonnement au cyanure chez un malade ayant reçu une dose totale de $400 \mathrm{mg}$ de Nitroprussiate de sodium $(10 \mathrm{mg} / \mathrm{kg})$. La détermination du taux sanguin et du taux urinaire de cyanure à l'autopsie a montré des taux respectifs de 0.5 et $0.3 \mathrm{mg} \%$. Des taux de thiocyanates trop bas pour être déterminés suggèrent un métabolisme anormal du thiocyanate.

La dose léthale de Nitroprussiate semble se situer autour de $7 \mathrm{mg} / \mathrm{kg}$. L'établissement anticipé d'une dose totale plus petite que $3.5 \mathrm{mg} / \mathrm{kg}$ pour toute la durée de l'intervention nous semble recommandable.

Chez des patients qui présentent une résistance anormale aux doses habituelles de Nitroprussiate ou incapables de maintenir leur niveau d'hypotension avec une dose constante de Nitroprussiate ou qui requièrent une dose totale anticipée supérieure à $3.5 \mathrm{mg} / \mathrm{kg}$, le taux de cyanure sanguin peut atteindre des seuils toxiques.

Les malades présentant le syndrome d'atrophie optique de Leber, une amblyopie tabagique et possiblement ceux souffrant d'autres atrophies nerveuses ne devraient pas recevoir de Nitroprussiate.

\section{REFERENCES}

1. Johnson, C.C. The actions and toxicity of sodium nitroprusside. Arch. Internat. Pharmacodynamic 35: 480 (1929).

2. Moroca, P.P., Bitte, E.M., \& Hale, D.E. et al. Clinical evaluation sodium nitroprusside as a hypotensive agent. Anesthesiology 23: 2: 193 (1963).

3. JoNes, G.O.M. \& Cole, P. Sodium nitroprusside as a hypotensive agent. Brit J. Anaes. 40: 804 (1968).

4. Vesey, C.J., Cole, P.V., Linnell, J.C., \& Wilson, J. Some metabolic effects of sodium nitroprusside in man. B.M.J. 2: 140 (1974).

5. Page, J.H., Concoran, H.P., \& Dustant, H.P., et al. Cardiovascular actions of sodium nitroprusside in animal and hypertensive patients, Amer. J. of Med. Sciences 248: 124 (1973).

6. EpPens, H. Sodium nitroprusside in hypotensive anaesthesia. Brit. J. Anaes. 45: 124 (1973).

7. AlDrIDGe, W.N. A new method for the estimation of microquantities of CN and SCN. The Analyst 70: 474 (1945).

8. Boxer, G.E. \& RICKArDS, J.C. Quantitative isolation and colorimetric determination of millimicrogram quantities of cyanide. Archives of Biochemistry and Biophysics 30:372 (1951).

9. Williams, R.T. Detoxication mechanisms. Chapman and Hall Ltd., London, England (1959).

10. BARKER, M.H. Blood cyanates in treatment of hypertension. J. Am. Med. Assn. 106: 762 (1936). 
11. Nounok, D.S., Glassock, R.J., \& Solomon, D.H. et al. Hypothyroidism following prolonged sodium nitroprusside therapy. Amer. J. Med. Sciences, 129 (1964).

12. Menrifield, A.Y. \& Blundell, M.D. Toxicity of sodium nitroprusside, B.J.A. 46: 324 (1974).

13. Dreisbach, R.H. Handbook of poisoning: diagnosis and treatment. Lange Med. Publications, Los Altos, Calif. pp. 218 (1971).

14. Wilson, J. Leber's heriditary optic atrophy: a possible defect of cyanide metabolism. Clin. Sci. 29: 505 ( 1965). 